\title{
SPLIT-ROOT NUTRITION OF SWEETPOTATO IN HYDROPONIC SYSTEMS
}

M.A. Sherif

Faculty of Agriculture

Soil Science Department

Minia University

Minia, Egypt
P.A. Loretan, A.A. Trotman, D.G. Mortley, J.Y. Lu

and L.C. Garner

Tuskegee University

NASA Center for CELSS

George Washington Carver Agricultural Experiment

Station

Tuskegee, AL 36088, U.S.A.

\begin{abstract}
Nutrient film technique (NFT) and deep water culture (DWC) hydroponic systems were used in a split-root study of the effect of four treatments on sweetpotato yield, the translocation of assimilates, and microbial population count. 'TU-155' cuttings $(15 \mathrm{~cm})$ were prerooted for 30 days in sand using deionized water and a modified half-Hoagland (MHH) solution. After 30 days, the plants were removed, and the roots of each were cleaned and split evenly between two sides of a channel (each 15 $\mathrm{cm}$ deep by $15 \mathrm{~cm}$ wide by $1.2 \mathrm{~m}$ long), four plants per channel. Replicated treatments were: MHH/MHH; MHH/Air, MHH/deionized water (DIW); and monovalent/divalent anions and cations (Mono/Dival). The entire experiment was repeated. Plants were harvested after growing for 120 days in a glasshouse. Storage roots, when produced, were similar in nutritive components. However, no storage roots were produced in Air or Mono channels and only a few in DIW suggesting inhibition of assimilate translocation. Fresh and dry weights for storage roots and foliage were highest in MHH/MHH in both NFT and DWC in both experiments. Solution samples were collected at 14-day intervals for microbial population profiling. Microbial counts $(4.20-7.49 \log \mathrm{cfu} / \mathrm{ml})$ were highest in Dival channels. The counts indicated that solution composition influenced population size, and they were relatively high in both systems.
\end{abstract}

Key words: divided root, translocation, Ipomoea batatas, microbial profile

\section{Introduction}

Hydroponic sweetpotato production using the nutrient film technique (NFT) has been studied as a possible means of food production for long-term manned space missions for the United States National Aeronautics and Space Administration (Hill et al., 1989; Bonsi et al., 1992). Once an effective nutrient solution was determined, much of the work concentrated on the optimal environmental conditions needed for growth of sweetpotato (Loretan, et al., 1992; Mortley et al., 1994). Some studies also investigated the effects that changes in the nutrient solution may have on yield. For example, Mortley et al. (1993) examined the effects of the N:K ratio (1:1.1, $1: 2.4$ and 1:3.6) on sweetpotato growth and found that it significantly influenced foliage fresh and dry weights of both cultivars.

Split-root techniques have been used to study plant nutrition by dividing the root system of a plant and placing each segment into adjoining containers in rooting media under different treatments. In several corn studies, Miller (1965) and Duncan 
and Ohlrogge (1958) used the split-root technique in soil treatments to examine root growth and nutrient uptake. In other studies, the split-root technique was used in hydroponic systems. For example, Lonergan et al. (1987) used a split-root nutrient solution treatment to study the translocation and function of zinc in the roots of wheat. In 1990, Sonneveld and Voogt used the split-root technique to study the response of tomatoes to an unequal distribution of nutrients in the root environment.

Also impacting the use of a nutrient solution is the microbiological load that it carries. The microbial population must be considered for space applications as a large count could clog the pores of a membrane being considered for use in sweetpotato culture. Also, a profile of microbial flora in the nutrient solution reservoir over the growing season of hydroponically-grown sweetpotato has to be determined since high microbial levels would influence the methodology used to treat spent nutrient solution.

The objective of this study was to examine the growth of sweetpotato in hydroponic split-root systems for yield, translocation of nutrients, and microbial profile using various solution treatments.

\section{Material and Methods}

Fifteen cm long vine cuttings of 'TU-155' sweetpotatoes were prerooted in sterilized sand in $4 \mathrm{~cm}$ (inner diameter) by $46 \mathrm{~cm}$ long, thin-walled CPCV cylindrical pipe stoppered at the bottom by a fine mesh plastic screen. Trickle tubes were programmed to feed water to the cuttings every other hour during the day alternating with modified half-Hoagland nutrient solution (Hoagland and Arnon, 1950). To keep humidity high around the cuttings, a plastic mesh canopy was draped about $30 \mathrm{~cm}$ above them and suspended close to the floor. The cuttings remained in the tubes for 30 days to allow root formation (Uewada, 1992). The cuttings, still housed in their cylinders, were then soaked in water until the sand loosened around their roots. The roots were washed clean and separated into two parts. The stems of the cuttings were positioned along a barrier dividing a rectangular growing channel into two sides, $0.15 \times 0.15 \times 1.2 \mathrm{~m}$ (wxhxl) each, and the split roots separated into the two sides. Plant cuttings were spaced at $0.25 \mathrm{~m}$ along this barrier, four plants per split channel. Black-white vinyl (white side up) covered the entire channel so that the root zone was kept dark. The vinyl was cut only to allow the plant stem to fit through. Channels were spaced so that plants were separated between adjacent channels by $0.53 \mathrm{~m}$.

For the nutrient film technique (NFT), each of eight split-root channels was on a $1 \%$ slope so that a thin film of solution would flow down past both split roots for each plant. Both sides of each channel (except for the Air treatment) were fed solution at the high end through $1.3 \mathrm{~cm}$ polyethylene piping pressurized by a small submersible pump (Teel Model IP680A, 1/200 HP, Chicago, IL) as described by Bonsi et al. (1992). The pump was located at the bottom of a 421 reservoir containing 30.4 liters of solution. The feed line from the pump included a bypass leading back to the reservoir to allow adjustment of the flow rate of the solution to the channel to $11 / \mathrm{min}$, to reduce the back pressure on the pump, and to assist in oxygenation of the solution. After flowing past the roots, the solution drained back into the reservoir via gravity through a drain plug at the low end of the channel. 
The DWC treatments were in eight of the same kind of channels except that they were not sloped but horizontal, and the drain hole was plugged. In this case, the 30.4 liters of solution was totally contained in each of the two sides of the channel with the split roots, and the solution was oxygenated for 15 minutes three times each day by using an aquarium air pump with a tube located in the solution.

For each system, each split-root channel had its own combination of four treatments (plus replications). Three of the treatments consisted of modified half-Hoagland $(\mathrm{MHH})$ nutrient solution in combination with itself or with air and deionized water (DIW). Thus, the combinations in three split-root channels became MHH/MHH, MHH/Air, MHH/DIW along with their replications. The last treatment combination, Mono/Dival, split the monovalent (Mono) and divalent (Dival) ions of the MHH solution. Table 1 shows the composition of the modified half-Hoagland nutrient solution and the Mono/Dival treatment.

In both NFT and DWC systems, treatment solutions were replaced every two weeks. If a solution was reduced to eight liters before two weeks, deionized water was added to bring the solution back to the 30.4 liter level. At replacement time, the $\mathrm{pH}$ of the solution was adjusted to 6 by use of either $1 \mathrm{~N} \mathrm{NaOH}$ or $\mathrm{HCl}$, but it was allowed to vary in the interim.

The two systems were set up in a glasshouse. As the vines formed on the plants, they were tied to vertical strings dropping 1 meter from the glasshouse structure above each growing channel. During the duration of both experiments, the glasshouse temperature ranged from 22 to $33^{\circ} \mathrm{C}$. Plants were harvested 120 days after planting or 90 days after transplanting into the split-root channels. All foliage was cut at the base of the stem, weighed fresh and dried for $72 \mathrm{~h}$ at $70{ }^{\circ} \mathrm{C}$ and reweighed dry. Yields were determined on a g/plant basis. A $25 \mathrm{~g}$ sample of randomly chosen storage roots from each plant was taken and dried at $70^{\circ} \mathrm{C}$ for 72 $\mathrm{h}$ to determine storage root dry weight. The fibrous root mat was weighed fresh, dried at $70{ }^{\circ} \mathrm{C}$ for $72 \mathrm{~h}$ and reweighed dry. The data for each experiment were analyzed and compared by treatment according to the general linear models procedure (SAS Institute, 1982).

Regarding translocation of assimilates, no measurements were made. Total plant response to the splitroot treatments was merely observed.

To study the microbial population profile, $15 \mathrm{ml}$ solution samples were collected from each reservoir from the "old" solution prior to its replacement at 14-day intervals and duplicate $1 \mathrm{ml}$ aliquots serially diluted in $9.0 \mathrm{ml}$ sterile water blanks. Total bacterial counts were determined on nutrient agar (Difco), yeast and mold on potato dextrose agar, and actinomycetes on actinomycete isolation agar. Plating in triplicate of appropriate dilutions was followed by incubation at room temperature $\left(24-28{ }^{\circ} \mathrm{C}\right)$. Counts were begun 5 days after plating, and plates were discarded when a final count was made at 21 days after plating. The counts determined represent the mean of the data for both experiments.

\section{Results and Discussion}

'TU-155' sweetpotato grew best in the channels which had the MHH/MHH treatment (Table 2) for both NFT and DWC systems. For this treatment, the fresh and dry weights of storage roots, foliage and fibrous roots were highest, and storage 
root number also tended to be highest. This was expected since the highest level of nutrients was available to the roots in this treatment. No storage roots were produced in the Air or Mono channels and, even though the Mono/Dival treatment provided the plants with the same though separated nutrients as those plants receiving the MHH/AIR and MHH/DIW, the lowest yields were obtained for Mono/Dival in both NFT and DWC. The results shown in Table 3 could partly explain this reduced growth response. When total plant foliage from all treatments in both systems was ground and analyzed, the elemental analysis was the same with two exceptions: $\mathbf{K}$ and $\mathrm{P}$ concentration was significantly lower in the Mono/Dival plants and Ca tended to be lower in that treatment in DWC. Sonneveld and Voogt (1990) found in their studies with tomato that, when nutrient solution electrical conductivity (EC) was not the same on both sides of a split-root channel, water was preferentially taken up from the lower EC solution and nutrients from the higher EC solution. According to this finding, nutrients would be taken up from the Dival side since it had the higher EC. It in fact produced the only storage roots in this treatment, even though it lacked $\mathbf{P}$ and $\mathbf{K}$, elements essential to good growth of sweetpotato. However, water was not taken up from the Mono side (data not shown).

The elemental analysis of Jones et al. (1991) using the most recent fully developed leaf at mid-season in a field study was used as a point of comparison of the elemental composition of foliage in the present study. $\mathrm{K}$ was found to be sufficient for all treatments except for Mono/Dival plants in which it was low (Table 3). $\mathbf{P}$ was high for each treatment except for Mono/Dival in which it was on the low side of the sufficient range (0.23-0.5\%). Sufficient levels existed for all other elements except for $\mathbf{N}$ (not shown) and $\mathrm{Zn}$, which were deficient for all treatments except the Mono/Dival. These low concentrations could be related to the fact that the analysis was done at harvest on composite samples of all foliage including stems, petioles and older and younger leaves instead of the most recently developed leaves.

A comparison of the elemental composition of the plant foliage to the fibrous roots indicated significant differences for each element (Table 4). This should not be surprising since each plays a different role in the plant's physiology and plant nutrients are more concentrated in foliage than in below-ground plant parts.

Although not included here, the analysis of elements in the plant foliage grown in the NFT and DWC systems was similar. The same was true for the fibrous roots.

Since no storage roots were produced in some treatments, only those produced in the MHH and Dival channel sides could be analyzed for nutritive composition. The results of this analysis are shown in Table 5. Though not statistically analyzed, it appears that there were no major differences except in protein content between either the system used or the treatments considered.

Under all but the MHH/MHH treatment, a distinct difference could be observed in the plants' total response to the split-root treatments. The plant side with the MHH-treated roots appeared productive; sides receiving the Air, DIW, Mono or Dival treatments produced few or no storage roots and showed some symptoms of deficiency (purple or yellow leaves and smaller size of leaves and storage roots). It was obvious that assimilates in the MHH-treated side were inhibited from translocating to the other side suggesting specific pathways for nutrient uptake and assimilation. Perhaps radioisotope tracers could be used in future studies to identify those pathways. 
Microbial population counts indicated that the composition of the plant nutrient solution influenced the size of the microbial population for sweetpotato grown in NFT (Figure 1). When a similar microbial assay was conducted on nutrient samples from DWC channels, composition again influenced population size. The Mono solution had fewer bacteria than the MHH, the Dival or the DIW treatments (Figure 2). Though not shown, the fungal count was higher in DWC than in NFT.

In conclusion, while sweetpotato storage roots can be successfully produced in split-root channels when a suitable nutrient solution is provided to both sides in NFT or DWC systems, the translocation of assimilates to the total plant appeared to be inhibited when only one side received the nutrient solution or if the monovalent and divalent anions and cations were separated in the channel. Alterations in the solution can affect plant growth and storage root yield. Nutritive content of the storage roots was not greatly affected by either the system or the treatment, but choice of treatment did affect microbial profiles in the solution.

\section{Acknowledgements}

This research was supported by funds from the U.S. National Aeronautics and Space Administration (Grant No. NAGW-2940), the U.S. Department of Agriculture Cooperative State Research Service (Grant No. ALX-SP-1), the U.S. Agency for International Development, and the Cultural and Education Bureau of Egypt Peace Fellowship Program.

\section{References}

Bonsi, C.K., Hill, W.A., Mortley, D.G., Loretan, P.A., Morris, C.E., and Carlisle, E.R., 1992. Growing sweetpotatoes for space missions using NFT. In: Sweetpotato technology for the 21st century. W. Hill, C. Bonsi and P. Loretan (eds.), Tuskegee University, Tuskegee, AL:110-119.

Duncan, W.G. and Ohlrogge, A.J., 1958. Principles of nutrient uptake from fertilizer bands. II. Root development in the band, Agron. J. 50:605-608.

Hill, W.A., Loretan, P.A., Bonsi, C.K., Morris, C.E., Lu, J.Y., and Ogbuchi, C., 1989. Utilization of sweetpotatoes in Controlled Ecological Life Support Systems (CELSS). Adv. Space Res. 9:29-41.

Hoagland, D.R. and Arnon, D.I., 1950. The water culture method for growing plant without soil. Calif. Agric. Exp. Sta. Circ. 347.

Jones, J.B., Wolf, B., and Mills, H., 1991. Plant analysis handbook. Micro-Macro Publishing, Inc., Athens, GA: 185

Lonergan, J.F., Kirk, G.J., and Webb, M.J., 1987. Translocation and function of Zn in roots. J. Plant Nutrition 10(9): 1247-1254.

Loretan, P.A., Bonsi, C.K., Mortley, D.G., Wheeler, R., Mackowick, C.L., Hill, W.A., Morris, C.E., Trotman, A.A., and David, P.P., 1994. Effects of several environmental factors on sweetpotato growth. Adv. Space Res. 14(11):277-280.

Miller, M.H., 1965. Influence of $\left(\mathrm{NH}_{4}\right)_{2} \mathrm{SO}_{4}$ on root growth and $\mathrm{P}$ absorption by corn from a fertilizer band. Agron J. 37:393-396.

Mortley, D.G., Bonsi, C.K., Hill, W.A., Loretan, P.A., and Morris, C.E., 1993. Irradiance and nitrogen to potassium ratio influences sweetpotato yield in nutrient film technique. Crop Sci. 33:782-784.

Mortley, D.G., Bonsi, C.K., Loretan, P.A., Hill, W.A., and Morris, C.E., 1994. Relative humidity influences yield, edible biomass, and linear growth rate of sweetpotato. HortScience 29(6):609-610. SAS Institute, 1982. SAS user's guide. Basic. SAS InsL, Cary, NC.

Sonneveld, C., and Voogt, W., 1990. Response of tomatoes (Lycopersicon esculentum) to an unequal 
distribution of nutrients in the root environment. Plant and Soil 124(2):251-256.

Uewada, T., Kcyota, M., Kitaya, Y., and Aiga, I., 1992. Hydroponic cultivation of sweetpotato. In: Sweetpotato technology for the 21st century W. A. Hill, C. Bonsi and P. Loretan (eds.), Tuskegee University, Tuskegee, AL: 120-125.

Table 1 - Nutrient solution compositions

a. Modified half-Hoagland (MHH) nutrient solution

Stock solution

Nutrient solution

\begin{tabular}{|c|c|c|c|}
\hline Item & $1 \mathrm{M}$ & $\mathrm{ml} /$ liter & $\begin{array}{r}\mathrm{ml} / 30.41 \\
\text { (8 US gal) }\end{array}$ \\
\hline 1 & $\mathrm{NH}_{4} \mathrm{H}_{2} \mathrm{PO}_{4}$ & 0.5 & 15.2 \\
\hline 2 & $\mathrm{KNO}_{3}$ & 3.0 & 91.2 \\
\hline 3 & $\mathrm{Ca}\left(\mathrm{NO}_{3}\right)_{2} \cdot 4 \mathrm{H}_{2} \mathrm{O}$ & - & - \\
\hline 4 & $\mathrm{CaCl}_{2} \cdot 2 \mathrm{H}_{2} \mathrm{O}$ & 2.0 & 60.8 \\
\hline 5 & $\mathrm{MgSO}_{4} \cdot 7 \mathrm{H}_{2} \mathrm{O}$ & 1.0 & 30.4 \\
\hline 6 & Solution $\mathrm{A}^{*}$ & 0.5 & 15.2 \\
\hline 7 & Solution $\mathrm{B}^{+}$ & 0.5 & 15.2 \\
\hline \multicolumn{4}{|c|}{ b. Monovalent (Mono)/divalent (Dival) nutrient solution } \\
\hline \multicolumn{2}{|c|}{ Monovalent (in 30.4 liters) } & \multicolumn{2}{|c|}{ Divalent (in 30.4 liters) } \\
\hline \multicolumn{2}{|c|}{$15.2 \mathrm{ml} \mathrm{NH}_{4} \mathrm{H}_{2} \mathrm{PO}_{4}$} & \multicolumn{2}{|c|}{$60.8 \mathrm{ml} \mathrm{CaCl}{ }_{2}$} \\
\hline \multicolumn{2}{|c|}{$91.2 \mathrm{ml} \mathrm{KNO}_{3}$} & \multicolumn{2}{|l|}{$30.4 \mathrm{ml} \mathrm{MgSO}$} \\
\hline \multicolumn{2}{|c|}{ (Items 1 and 2 above). } & \multicolumn{2}{|c|}{$\begin{array}{l}15.2 \mathrm{ml} \text { Solutions } A \text { and } B \\
\text { (Items } 4,5,6 \text { and } 7 \text { above) }\end{array}$} \\
\hline
\end{tabular}

Solution $\mathrm{A}$ is a micronutrient composition consisting of (in $\mathrm{g}$ liter ${ }^{-1}$ ): 2.86 $\mathrm{H}_{3} \mathrm{BO}_{3}, 1.81 \mathrm{MnCl}_{2} .4 \mathrm{H}_{2} \mathrm{O}, 0.22 \mathrm{ZnSO}_{4} .7 \mathrm{H}_{2} \mathrm{O}, 0.08 \mathrm{CuSO}_{4} .5 \mathrm{H}_{2} \mathrm{O}, 0.09$ $\mathrm{H}_{2} \mathrm{MoO}_{4} \cdot \mathrm{H}_{2} \mathrm{O}-85 \% \mathrm{MoO}_{3}$

+ Solution B consists of (in $\left.\mathrm{g} \mathrm{liter}{ }^{-1}\right): 5 \mathrm{Fe}$ Chelate $(10 \% \mathrm{Fe})$ Sequestrene 330 
Table 2 - Yield of 'TU-155' sweetpotato' in NFT and deep water culture using split-root channels

\begin{tabular}{|c|c|c|c|c|c|c|c|c|c|c|c|c|c|c|}
\hline \multirow{3}{*}{ Treatment } & \multicolumn{6}{|c|}{ Storage roots } & \multicolumn{4}{|c|}{ Fibrous roots } & \multicolumn{4}{|c|}{ Foliage } \\
\hline & \multirow{2}{*}{\multicolumn{2}{|c|}{ No }} & \multicolumn{2}{|c|}{ Fr wt } & \multicolumn{2}{|c|}{ Dr wt } & \multicolumn{2}{|c|}{ Fr wt } & \multicolumn{2}{|c|}{ Dr wt } & \multicolumn{2}{|c|}{ Fr wt } & \multicolumn{2}{|c|}{ Drwt } \\
\hline & & & \multicolumn{4}{|c|}{$\mathrm{g} /$ plant } & \multicolumn{4}{|c|}{ g/plant } & \multicolumn{4}{|c|}{ g/plant } \\
\hline \multicolumn{15}{|c|}{ NFT system } \\
\hline MHH/MHH & 4.4 & $\mathrm{a}^{+}$ & 701 & $\mathbf{a}$ & 125 & $\mathrm{a}$ & 225 & $\mathbf{a}$ & 10.5 & $\mathrm{a}$ & 514 & $\mathbf{a}$ & 69 & $\mathbf{a}$ \\
\hline MHH/DIW & 4.1 & $\mathbf{a}$ & 455 & b & 67 & b & 160 & b & 7.0 & $\mathrm{c}$ & 283 & b & 35 & b \\
\hline MHH/Air & 3.3 & $\mathrm{ab}$ & 446 & $b$ & 40 & c & 174 & b & 8.6 & b & 292 & b & 39 & $\mathrm{~b}$ \\
\hline Mono/Dival & 2.3 & $\mathrm{~b}$ & 113 & $\mathrm{c}$ & 13 & d & 48 & c & 3.9 & d & 42 & c & 8 & $\mathrm{c}$ \\
\hline \multicolumn{15}{|c|}{ Deep water culture } \\
\hline MHH/MHH & 2.9 & $\mathbf{a}$ & 395 & $\mathbf{a}$ & 57.9 & $\mathrm{a}$ & 216 & $\mathbf{a}$ & 9.5 & $\mathbf{a}$ & 331 & $\mathbf{a}$ & 37.8 & $\mathbf{a}$ \\
\hline MHH/DIW & 2.4 & $a b$ & 266 & b & 30.2 & $\mathbf{b}$ & 144 & b & 7.1 & $b$ & 178 & b & 22.8 & b \\
\hline MHH/Air & 1.9 & $\mathrm{bc}$ & 245 & b & 22.1 & bc & 136 & $\mathbf{b}$ & 6.5 & b & 171 & b & 21.0 & b \\
\hline Mono/Dival & 1.3 & $\mathrm{c}$ & 81 & $\mathrm{c}$ & 8.1 & $\mathrm{c}$ & 105 & $\mathrm{~b}$ & 3.5 & $\mathbf{c}$ & 33 & $\mathrm{c}$ & 6.6 & $\mathrm{c}$ \\
\hline
\end{tabular}

* Mean of 16 plants

+ Mean separation within columns by DMRT. Means followed by the same letter are not significantly different (5\% level) 
Table 3 - Elemental composition* of total foliage for sweetpotato grown in NFT and deep water culture

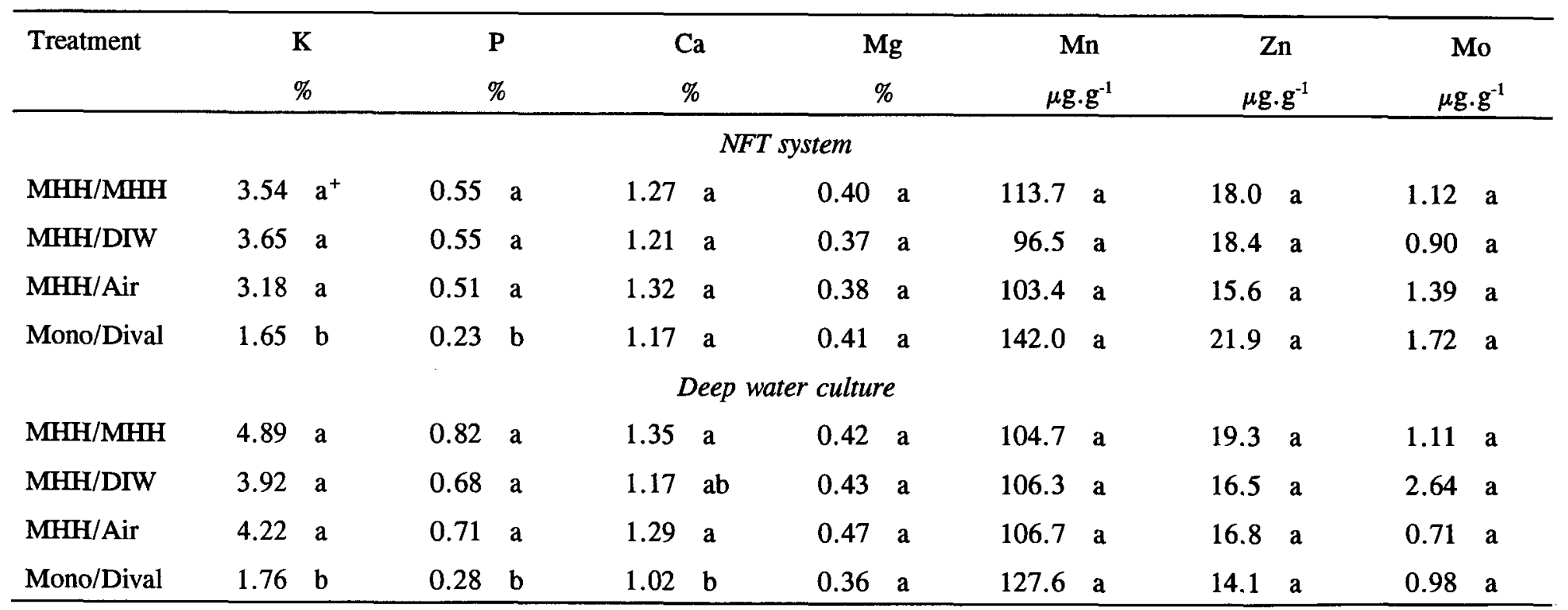

* Mean of 16 plants

+ Mean separation within columns by DMRT. Means followed by the same letter are not significantly different (5\% level) 
Table 4 - Comparison of the elemental composition of foliage and fibrous roots

\begin{tabular}{|c|c|c|c|c|c|c|c|c|}
\hline \multirow[b]{3}{*}{ Foliage } & \multirow{2}{*}{$\begin{array}{l}\mathrm{K} \\
\% \\
\end{array}$} & \multirow{2}{*}{$\begin{array}{l}\mathbf{P} \\
\% \\
\end{array}$} & \multirow{2}{*}{$\begin{array}{c}\mathrm{Ca} \\
\% \\
\end{array}$} & \multirow{2}{*}{$\begin{array}{c}\mathbf{M g} \\
\% \\
\end{array}$} & \multirow{2}{*}{$\begin{array}{c}\mathrm{Mn} \\
\mu \mathrm{g} \cdot \mathrm{g}^{-1} \\
\end{array}$} & \multirow{2}{*}{$\begin{array}{c}\mathrm{Zn} \\
\mu \mathrm{g} \cdot \mathrm{g}^{-1} \\
\end{array}$} & \multirow{2}{*}{\multicolumn{2}{|c|}{$\begin{array}{c}\text { Mo } \\
\mu \mathrm{g} \cdot \mathrm{g}^{-1} \\
\end{array}$}} \\
\hline & & & & & & & & \\
\hline & 3.30 & 0.53 & $1.22 \mathrm{a}$ & 0.41 a & 112.9 a & $68.5 \mathrm{a}$ & 1.36 & $\mathbf{b}$ \\
\hline Fibrous roots & 1.80 & 0.16 & $0.59 \quad b$ & 0.23 & 40.9 & $17.5 \quad b$ & 114.1 & $\mathbf{a}$ \\
\hline
\end{tabular}

Table 5 - Nutritive composition of sweetpotatoes ${ }^{*}$ grown in split-root hydroponic systems

\begin{tabular}{|c|c|c|c|c|c|c|c|}
\hline \multirow[b]{2}{*}{ Treatment } & \multirow[b]{2}{*}{$\begin{array}{l}\text { Starch } \\
\% \\
\end{array}$} & \multirow[b]{2}{*}{$\begin{array}{l}\text { Protein } \\
\%\end{array}$} & \multirow[b]{2}{*}{$\begin{array}{l}\text { Ash } \\
\% \\
\end{array}$} & \multicolumn{4}{|c|}{ Vitamin } \\
\hline & & & & $\begin{array}{l}\beta \text {-carotene } \\
\mathrm{mg} / 100 \mathrm{~g}\end{array}$ & $\begin{array}{l}\mathrm{C} \\
\mathrm{mg} / 100 \mathrm{~g}\end{array}$ & $\begin{array}{l}\mathrm{B}_{1} \\
\mathrm{mg} / 100 \mathrm{~g}\end{array}$ & $\begin{array}{l}\mathrm{B}_{2} \\
\mu \mathrm{g} \cdot \mathrm{g}^{-1}\end{array}$ \\
\hline \multicolumn{8}{|c|}{ NFT systeem } \\
\hline MHH & 10.4 & 0.77 & 0.89 & 4.53 & 3.78 & 2.19 & 0.23 \\
\hline \multicolumn{8}{|c|}{ Deep water culture } \\
\hline MHH & 11.2 & 0.36 & 0.96 & 4.99 & 3.73 & 2.03 & 0.20 \\
\hline Dival & 12.5 & 0.42 & 0.57 & 4.96 & 4.05 & 2.49 & 0.15 \\
\hline
\end{tabular}

* Fresh weight basis for storage roots 


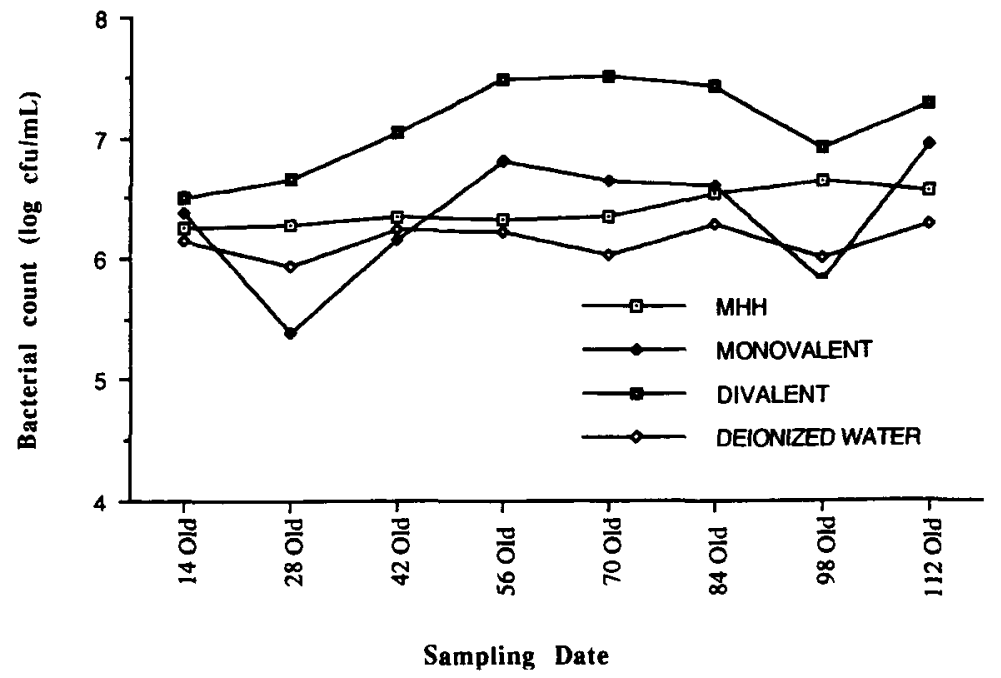

Figure 1 - Bacterial counts $(\log \mathrm{cfu} / \mathrm{ml})$ in reservoirs used to supply nutrients in a NFT-system

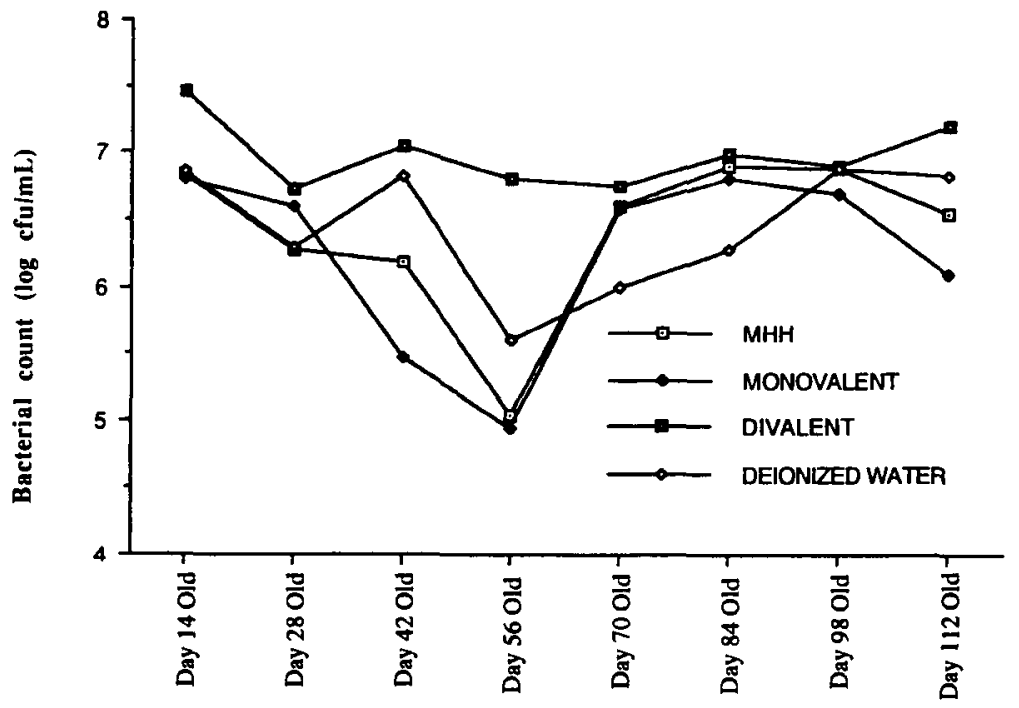

Sampling Date

Figure 2 - Bacterial counts $(\log \mathrm{cfu} / \mathrm{ml})$ in channels supplying nutrients in a deepwater hydroponic system 